\title{
The role of brand self-relevance in developing brand loyalty: a study on the brand loyalty for Honda
}

\begin{abstract}
This study investigates the role of brand self-relevance in developing brand loyalty on the automotive brand, Honda. In-depth interviews of 34 Honda owners in Malaysia were conducted. Those interviewed were asked on their feelings, experiences and loyalty towards Honda. The study conceptualised a research model combining Dick and Basuô (1994) customer loyalty framework and Sirgyô (1986) self-congruity theory. Results demonstrated there are two main self-relevance factors influencing consumersôbrand loyalty, which are product or brand user image congruity and need for self-expression. Specifically, study showed need of self-expression plays a significant role in influencing brand loyalty to portray consumersôideal, social and ideal-social self-images. Results also reveal brand self-relevance plays a significant role to both behavioural and attitudinal brand loyalty. Results illustrated brand self-relevance plays a more significant role in influencing consumers towards true loyalty than latent, spurious or no loyalty. This study suggests brand managers, advertisers and companies should focus on brand self-relevance in developing brand loyalty strategies to capture brandôs target market and retain them for a long duration of time. Findings provide a more specific direction in developing brand communication strategies and marketing plans to create strong and sustainable brand, retaining greater brand loyalty of the customers.
\end{abstract}

Keyword: Brand self-relevance; Customer loyalty; Self-congruity theory; Brand communication; Thematic analysis 